\title{
Hubungan Regulasi Diri Dengan Status Gizi pada Remaja Akhir
}

\author{
di Kota Denpasar
}

\author{
A.A. Istri Mira Pramitya dan Tience Debora Valentina \\ Program Studi Psikologi, Fakultas Kedokteran, Universitas Udayana \\ myra.pramitya@gmail.com
}

\begin{abstract}
Abstrak
Permasalahan remaja yang menjadi perhatian utama di bidang kesehatan salah satunya merupakan masalah gizi. Obesitas dan anemia merupakan dua hal yang rentan dihadapi remaja terkait permasalahan gizi. Maraknya restoran cepat saji yang menjamur sangat kontradiktif dengan fenomena obesitas yang telah menjadi epidemiologi global dan distorsi pada citra tubuh mempunyai kaitan dengan anemia terkait penyusutan bobot tubuh. Pemenuhan gizi dapat dilihat melalui status gizi individu dan regulasi diri merupakan pendekatan psikologis yang terkait pembentukan status gizi yang optimal karena terkait kemampuan individu dalam mengontrol perilaku, mengatur hasrat ataupun emosi dan mengendalikan dorongan perilaku.

Tujuan penelitian ini adalah untuk menelusuri lebih lanjut tentang hubungan regulasi diri dengan status gizi pada remaja akhir di Kota Denpasar. Metode penelitian yang digunakan adalah kuantitatif. Subjek dalam penelitian ini adalah remaja akhir yang berada pada kisaran 17-19 tahun. Metode pengumpulan data menggunakan skala regulasi diri $(r=0,936 ; \alpha=0,273-0,625)$ dan pengukuran indeks massa tubuh untuk mengukur status gizi.

Hasil uji analisis statistik yang digunakan adalah analisis nonparametrik Spearman menunjukkan nilai signfikansi yaitu $\mathrm{p}=0,822$ yang mengindikasikan Hipotesis Null diterima yaitu tidak adanya hubungan antara regulasi diri dengan status gizi pada remaja akhir di Kota Denpasar. Ditolaknya hipotesis alternatif dikarenakan oleh teori yang digunakan belum banyak diuji dalam penelitian lain, teknik pengambilan sampel yang kurang representatif dan adanya faktor-faktor internal dan eksternal yang lebih mempunyai hubungan dengan status gizi akan diulas lebih lanjut dalam pembahasan.
\end{abstract}

Kata kunci: Regulasi diri, status gizi, remaja akhir.

\begin{abstract}
One of the nutritional problem in adolescent is about health which it's also major concern in the health sector. Obesity and anemia are two things that vulnerable adolescents facing problem related to nutritional problem. Proliferation of fast food restaurant are very contradictory to the widespread phenomenon of obesity which it's been a global epidemiology and body image distortion is concerned with anemia which it's related with losing body weight. Nutrition fulfillment can be seen through optimal nutrition status as related to the ability of people to control their behavior, emotion and mind (drives).

The purpose of this research is to explore the relationship between self-regulation with nutritional status of fulfillment. This research used quantitative methods. The subject of this research are 280 late adolescents in Denpasar. Data was gathered by using self-regulation scale $(\mathrm{r}=0,936 ; \alpha=0,273-0,625)$ Physical measurement with Body Mass Index (BMI) is used to measure nutritional status. Data analysis is performed by Spearman analysis.

The result shows that there is correlation coefficient score (p) is 0,822 . It means there is no significant relationship between self-regulation and nutritional status of late adolescents in Denpasar. Therefore, alternative hypothesis is rejected, it can caused by the theory that used in this research hasn't been much tested in other studies, the sampling technique is less representative and there are internal and external factor which are more related with nutritional status and it will be discussed later.
\end{abstract}

Key words: self-regulation, nutritional status, late adolescent. 


\section{LATAR BELAKANG}

Fase remaja yang ditandai dengan kematangan fisiologis seperti pembesaran jaringan sampai organ tubuh membuat remaja memerlukan kebutuhan nutrisi yang spesial (Tim Penulis Poltekkes Depkes Jakarta I, 2010). Kelompok remaja merupakan salah satu perhatian utama di bidang kesehatan pada lima tahun terakhir ini. Hal ini disebabkan oleh karena keunikan gaya hidup remaja apabila dibandingkan dengan kelompok usia lain (Sulaiman, 2009).

Masa remaja adalah fase individu mengalami perkembangan sehingga dapat mencapai kematangan secara mental, emosional, sosial serta fisik. Salah satu permasalahan yang dihadapi oleh remaja ialah permasalahan yang berkaitan dengan gizi. Gizi merupakan zat-zat yang terkandung di dalam makanan yang dikonsumsi oleh manusia sehari-hari dan memberikan manfaat bagi tubuh. Gambaran pemenuhan gizi dalam kehidupan manusia dapat diketahui dengan melihat status gizinya. Status gizi merupakan suatu keseimbangan antara gizi yang dikonsumsi dan penggunaannya oleh tubuh. Kebutuhan gizi pada remaja terdiri dari energi, protein, zinc, mineral, dan vitamin (Tim Penulis Poltekkes Depkes Jakarta I). Salah satu cara sederhana yang dapat digunakan untuk menentukan status gizi adalah antropometri gizi. Antropometri berasal dari kata antropos dan metros. Antropos artinya tubuh dan metros artinya ukuran. Jadi antropometri adalah ukuran dari tubuh (Supariasa, 2002). Cara sederhana yang dapat digunakan untuk menentukan status gizi pada remaja adalah dengan mengukur Indeks Massa Tubuh (IMT) atau Body Mass Index (BMI). IMT dapat membantu untuk mengidentifikasi remaja yang secara signifikan berisiko mengalami kelebihan berat badan (Supariasa, 2002). Klasifikasi status gizi menurut baku rujukan WHO-NCHS terdiri dari gizi kurang, gizi normal, gizi lebih, dan obesitas. Status gizi dipengaruhi oleh beberapa faktor. Suhardjo (2003) menjelaskan bahwa faktor-faktor yang mempengaruhi status gizi yaitu terdiri dari faktor internal yang mencakup genetik, asupan makanan, dan penyakit infeksi serta faktor eksternal yang terdiri dari sector pertanian, ekonomi, sosial dan budaya serta pengetahuan gizi.

Berbagai permasalahan tentang gizi dan kesehatan yang dihadapi remaja mempunyai hubungan yang saling berkaitan, sehingga diperlukan penanganan yang komprehensif. Adapun masalah-masalah gizi yang dialami pada fase remaja adalah obesitas dan anemia (Khomsan, 2003).

Obesitas merupakan salah satu masalah gizi di dunia sampai saat ini. Tahun 1998 WHO menyatakan bahwa obesitas telah menjadi epidemi global yang terjadi pada orang dewasa dan anak-anak dengan jumlah kasus lebih dari 300 juta orang di dunia. Obesitas telah mengakibatkan kematian sebanyak 30.000 orang setiap tahun di Inggris (House of Common, 2004).
Obesitas merupakan kondisi terjadinya penumpukan lemak dalam tubuh yang berlebihan. Semenjak 30 tahun yang lalu, kasus obesitas dua kali lebih banyak ditemukan pada remaja. Remaja yang memiliki berat badan berlebihan akan meningkatkan risiko remaja tersebut mengalami obesitas. Remaja yang mengalami kegemukan akan cenderung tetap kegemukan ketika dewasa (Medicastore, 2010).

Obesitas adalah penumpukan lemak yang berlebihan di dalam badan atau kegemukan yang berlebihan. Papalia dan Olds (2001) mengatakan bahwa obesitas atau kegemukan terjadi jika individu mengkonsumsi kalori yang berlebihan dari yang mereka butuhkan. Sarafino (1998) juga mengatakan bahwa obesitas adalah sebagai suatu simpanan yang berlebih dalam bentuk lemak yang berdampak buruk bagi kesehatan. Pengertian obesitas dalam psikologis menurut Wurtman dan Wurtman (dalam Satria, 2008) adalah simpanan energi yang berlebihan dalam bentuk lemak yang berdampak buruk bagi kesehatan dan perpanjang usia.

Berdasarkan data Riset Kesehatan Dasar (Riskesdas) khususnya kasus obesitas di Bali, prevalensi kejadian obesitas pada remaja akhir mencapai $10,4 \%$ pada tahun 2007. Data yang lebih spesifik menguraikan perbedaan persentase kejadian obesitas pada laki-laki dan perempuan terdapat pada data riskesdas tahun 2010 yaitu memaparkan bahwa remaja perempuan yang obesitas mencapai $11,9 \%$ dan laki-laki mencapai $8,8 \%$. Menurut data riskesdas, kasus obesitas yang terjadi didukung pula dengan karakteristik tempat tinggal, status ekonomi dan tingkat pendidikan. Hal tersebut ditunjukkan dengan prevalesi kejadian obesitas yang terjadi di Indonesia menurut pendapatan perkapita pada laki-laki mencapai $15 \%$ dan perempuan mencapai $21,3 \%$. Untuk karakteristik tempat tinggal, laki-laki dan perempuan yang tinggal di daerah perkotaan mempunyai angka prevalensi lebih tinggi untuk kejadian obesitas dibandingkan pada laki-laki dan perempuan yang tinggal di pedesaan. Hal tersebut ditandai dengan prevalensi obesitas pada laki-laki mencapai $10,5 \%$ dan perempuan mencapai $18,7 \%$. Selain itu, menurut data riskesdas, tingkat pendidikan yang lebih tinggi merupakan hal yang berkaitan dengan kejadian obesitas. Pada laki-laki mencapai $18,5 \%$ dan perempuan mencapai $18,1 \%$. Riskesdas juga memaparkan terkait dengan peningkatan kejadian obesitas yang terjadi berimplikasi pada permasalahan kesehatan bagi penduduk karena obesitas dapat memicu berbagai penyakit kronis seperti diabetes, hipertensi dan lainlain (Riskesdas, 2010).

Anna (2011) memaparkan lebih lanjut bahwa remaja perempuan gemuk meningkat dari 23,8 persen menjadi 26,9 persen. Remaja laki-laki gemuk meningkat dari 13,9 persen menjadi 16,6 persen. Dalam artikel online Kompas tersebut juga disebutkan bahwa kelebihan berat badan dan obesitas mengancam generasi muda Indonesia. Kejadian yang salah satunya disebabkan oleh kelebihan gizi tersebut, justru akan 
membawa kerentanan berbagai penyakit tak menular yang membahayakan.

Penyebab obesitas sangatlah kompleks, tidak hanya faktor genetik namun juga gaya hidup dan faktor lingkungan berperan dominan dengan kejadian obesitas. Dari segi gaya hidup, gaya hidup yang tidak aktif dan perilaku makan yang tidak sehat menjadi penyebab obesitas. Perilaku makan yang tidak sehat dapat menjadi penyebab penting terjadinya obesitas dan salah satu bentuknya adalah mengkonsumsi makanan cepat saji. Makanan cepat saji memang memiliki kandungan gizi, seperti lemak, protein, vitamin, dan mineral, tetapi makanan ini juga mengandung sejumlah besar lemak jenuh, kolesterol, garam natrium, dan kalori dalam jumlah besar serta hanya sedikit mengandung serat. Rata-rata makanan siap saji mengandung sebanyak $50 \%$ dari jumlah kalori yang diperlukan sehari, berkisar antara 400 kalori sampai 1500 kalori, dan 40 - 60\% kalori dalam makanan cepat saji ini berasal dari lemak. Angelina (2010) lebih lanjut memaparkan berkaitan tentang makanan cepat saji bahwa makanan cepat saji yang cenderung digemari banyak orang sayangnya tidak memiliki kandungan gizi cukup yang dipengaruhi oleh tubuh.

Fenomena maraknya restoran cepat saji yang beredar di perkotaan khususnya daerah Kota Denpasar menuai kontradiksi tersendiri bagi kejadian obesitas khususnya di daerah Denpasar. Perkembangan restoran cepat saji di Bali dewasa ini terus mencapai rata-rata $35,01 \%$ per tahun, sampai saat ini jumlah restoran cepat saji mencapai 18 buah sehingga memiliki persentase lebih dari $75 \%$ yang berlokasi di daerah Denpasar serta Badung (Dinas Perindag Bali, 2003). Jika dilihat dari jumlah penduduk Bali pada tahun 2002 yaitu sebanyak 3.090.497 jiwa, dengan tingkat pertumbuhan ratarata $1,02 \%$ per tahun menurut BPS Bali tahun 2003, maka pertumbuhan jumlah restoran cepat saji lebih cepat dibandingkan dengan pertumbuhan penduduk (Disperindag, 2010).

Ariani (2005) lebih lanjut menjabarkan bahwa seperti di kota-kota besar lainnya, makanan cepat saji kini memang telah menjadi gaya hidup di Denpasar. Sebagian besar masyarakat justru merasa bangga bila mampu memberikan anak mereka makan di restoran cepat saji. Gaya hidup tersebut kini mulai membangun hal baru, yakni obesitas pada anakanak begitu pula pada remaja.

Masalah gizi lain yang sangat erat kaitannya dengan remaja ialah anemia. Prevalensi terjadinya anemia pada remaja Indonesia menurun yaitu sekitar 40-88\%. Sumber data lain memaparkan remaja yang berada pada kisaran usia 13-19 tahun di Jawa Barat mempunyai prevalensi KEP 16,8\% dan prevalensi anemia 42,4\%. Sedangkan di Bali prevalensi KEP 30,2 persen dan prevalensi anemia 44,5 persen (Damayanti, 2009).
Anemia merupakan suatu keadaan jumlah hemoglobin dalam darah kurang dari normal. Zat ini dibuat di dalam sel darah merah, sehingga anemia dapat terjadi baik karena sel darah merah mengandung terlalu sedikit hemoglobin maupun karena jumlah sel darah yang tidak cukup. Sel-sel darah merah membawa oksigen dari paru-paru ke jaringan-jaringan dan mengangkut karbondioksida dari jaringan-jaringan ke paru-paru. Setiap keadaan yang mengurangi kemampuan membawa oksigen dari sel-sel darah merah akan mengurangi pemasokan oksigen ke jaringanjaringan termasuk otak dan otot. Gejala-gejala dari anemia tersebut akan mencakup kelesuan, konsentrasi yang buruk dan kelemahan (Purnamasari, 2011).

Remaja mempunyai gaya hidup yang dinamis dan aktif serta kepedulian yang tinggi akan penampilan. Dua ciri terakhir inilah yang menyebabkan remaja memiliki persepsi yang salah terhadap bentuk tubuhnya (citra tubuh). Ciri itu juga yang berpotensi menyebabkan remaja berperilaku makan yang salah. Dalam artikel "Citra Tubuh dan Gangguan Makan pada Remaja", disebutkan bahwa persepsi citra tubuh yang negatif membuat remaja mempunyai perilaku makan yang salah sehingga para remaja tidak jarang mengalami Anorexia nervosa dan bulimia nervosa yang berdampak pada penurunan berat badan atau bobot tubuh, penderita anorexia nervosa akan terus berupaya membatasi secara ketat makanan yang dikosumsinya hingga di bawah jumlah yang seharusnya dikonsumsi. Akibatnya berat badan terus menurun dan akan menderita kekurangan gizi yang berat. Perlahan-lahan penderita akan kehilangan selera makannya. Pada bulimia nervosa, gangguan pola makan dicirikan oleh konsumsi makan secara tidak terkendali yang diikuti oleh tindakan mengeluarkan kelebihan kalori tubuh. Bertititik tolak dari hal tersebutlah, penurunan berat badan atau bobot tubuh akan mengakibatkan seseorang mengalami anemia karena mereka kekurangan zat besi dan asam folat yang dikarenakan oleh diet yang berlebihan (Siagian, 2011).

Berbagai pemaparan tentang masalah gizi remaja yang mencakup anemia dan obesitas, dapat dirangkum bahwa permasalahan gizi remaja tersebut tidak lepas dari cara remaja mengatur pola makan, mengatur diri untuk melakukan aktivitas fisik dan pencitraan remaja terhadap tubuh mereka sendiri. Semua ini tidak lepas dari regulasi diri individu itu sendiri. Regulasi diri merupakan hal yang dilakukan individu untuk mengubah respon sebelumnya yang ditampilkan mengenai stimulus tertentu untuk mencapai respon baru (perilaku baru), seperti mengendalikan impuls perilaku (dorongan perilaku), mengontrol hasrat, mengendalikan emosi serta pikiran. Beberapa yang berkaitan dengan regulasi diri adalah observasi diri, evaluasi diri dan penguatan oleh diri sendiri. Hal lain yang berkaitan dengan regulasi diri diantaranya efikasi diri, pembentukan nilai moral dan penundaan terhadap kepuasan (Wulandari \& Zulkaida, 2007). 


\section{A. A. I. M. PRAMITYA DAN T. D VALENTINA}

Adapun komponen-komponen regulasi diri yaitu, pertama receiving yakni menerima informasi yang relevan. Dalam hal ini individu menerima infomasi-informasi dari luar untuk mengkaji suatu permasalahan. Kedua yaitu evaluating yakni mengevaluasi permasalahan. Individu dalam hal ini membuat pemikiran-pemikiran tentang seberapa krusial suatu permasalahan. Ketiga yaitu triggering yakni membuat suatu perubahan. Perubahan yang dibuat individu tersebut merupakan hasil dari evaluasi. Keempat yaitu searching yakni mencari solusi. Adanya kebutuhan mencari jalan keluar ataupun solusi ini sebagai hasil dari perbedaan maupun pertentangan dalam menghadapi suatu permasalahan. Kelima yaitu formulating yakni merancang suatu rencana dalam rangka menentukan hal-hal yang akan dilakukan baik dari segi waktu dan aktivitas terkait tujuan yang ingin dicapai. Keenam yaitu implementating yaitu menerapkan rencana-rencana yang telah dibuat sebagai realisasi pemikiran-pemikiran sebelumnya. Terakhir yaitu assessing yaitu pengukuran efektifitas dari segala tindakan yang telah dibuat.

Selain adanya komponen-komponen mengenai regulasi diri, terdapat pula faktor-faktor yang mempengaruhi regulasi diri yaitu faktor internal dan eksternal. Faktor internal terdiri dari self-observation atau observasi diri adalah pengamatan pribadi yang dilakukan oleh individu, judgmental process atau proses penilaian adalah membandingkan perilaku dengan norma atau standar yang menjadi acuan individu, dan self-response atau reaksi diri adalah reaksi-reaksi yang timbul berdasarkan hasil pengamatan diri. Faktor eksternal terdiri dari standard atau dasar perilaku. Dasar perilaku menjadi acuan dalam mengevaluasi tingkah laku dan reinforcement yaitu penguatan yang menjadi hal yang digunakan untuk mempertahankan perilku yang diinginkan.

Adanya beberapa penelitian menunjukkan bahwa pendidikan gizi seimbang lebih efektif apabila difokuskan pada aspek perilaku. Pendekatan yang terfokus pada perilaku menunjukkan bahwa program pendidikan gizi terpusat pada perubahan perilaku individu dalam pemilihan makanan, dan bukan hanya pada penyebarluasan informasi tentang makanan atau gizi secara umum saja. Hal tersebut menyebabkan adanya perubahan paradigma untuk mengubah target pendidikan gizi seimbang, yaitu dari bertujuan meningkatkan pengetahuan, ke perubahan faktor psikologis sebagai variabel perantara yang memengaruhi perubahan perilaku dalam pemilihan makanan. Salah satu pendekatan yang dapat dilakukan adalah regulasi diri (Kolopaking, Firmansyah, Umar \& Fahmida, 2010).

Masih erat kaitannya dengan permasalahan gizi, berdasarkan pemaparan sebelumnya, obesitas pun dapat dinyatakan sebagai salah satu faktor risiko penyakit kardiovaskular seperti diabetes. Salah satu penelitian yang meneliti tentang penyakit diabetes menemukan adanya dinamika regulasi diri pada penderita diabetes. Pada penelitian tersebut dijelaskan bahwa regulasi diri merupakan pendekatan yang baik untuk mencapai kondisi yang lebih sehat karena dalam regulasi diri tersebut mencakup pengarahan diri atau pengaturan diri seseorang dalam berperilaku. Jika dikaitkan dengan diabetes itu sendiri sebagai akibat dari obesitas, proses regulasi diri dapat diterapkan karena pasien perlu meregulasi proses metabolik seperti memonitor dan menyesuaikan kadar gula dalam darah (Ningrum \& Hasanat, 2007).

Untuk permasalahan anemia pada remaja, menurut DeMaeyer (dalam Tim Penulis Poltekkes Depkes Jakarta I, 2010) regulasi diri berperan dalam pencegahan anemia dalam bntuk pendidikan kesehatan tentang pola makan sehat sehingga perilaku makan remaja lebih terarah dan dapat terhindar dari anemia, salah satunya dengan memperkaya makanan pokok dengan zat besi seperti hati, sayuran berwarna hijau dan kacang-kacangan.

Berdasarkan hasil pemaparan permasalahan gizi pada remaja tersebut, sekiranya sangat penting untuk melihat kontribusi lebih lanjut mengenai regulasi diri yang dimiliki oleh remaja terhadap status gizi dari remaja itu sendiri. Untuk itu, pada penelitian ini, peneliti tertarik untuk megetahui hubungan regulasi diri dengan status gizi pada remaja akhir di Kota Denpasar. Penelitian ini diharapkan dapat memberikan kontribusi edukasi di dunia akademis khususnya psikologi kesehatan dan dapat menjadi acuan khususnya bagi para remaja untuk menuju pola hidup sehat dan meningkatkan pengetahuan, sikap dan perilaku masyarakat tentang pola konsumsi makanan yang beragam, bergizi seimbang, dan aman.

\section{METODE}

\section{Variabel dan definisi operasional}

Variabel penelitian merupakan segala bentuk hal yang dipelajari oleh peneliti sehingga diperoleh informasi mengenai hal-hal yang berkaitan tentang variabel yang ingin diketahui tersebut dan kemudian ditarik kesimpulannya (Sugiyono, 2009).Pada penelitian ini, terdiri dari dua variabel yaitu, variabel bebas dan variabel tergantung.

Variabel Bebas merupakan variabel yang sifatnya mempengaruhi maupun yang menjadi penyebab timbulnya perubahan dari variabel dependen atau terikat (Sugiyono, 2009).Variabel bebas pada penelitian ini adalah regulasi diri.Variabel tergantung merupakan variabel yang dipengaruhi atau yang menjadi akibat, karena adanya variabel bebas (Sugiyono, 2009). Variabel tergantung pada penelitian ini adalah status gizi.

Definisi operasional dari variabel regulasi diri adalah kemampuan untuk merencanakan, mengarahkan, dan memonitor perilaku individu dengan fleksibel untuk mengubah keadaan.

Definisi operasional dari variables status gizi pada remaja awal adalah hasil penilaian status gizi pada remaja usia 17-19 tahun dengan pengukuran indeks pengukuran 
antropometri gizi yaitu dengan pengukuran indeks massa tubuh. Status gizi kurang bila IMT dibawah 5 persentil, status gizi normal bila IMT dari 5 persentil sampai dibawah 85 persentil, status gizi lebih bila IMT dari 85 persentil sampai dibawah 95 persentil dan obesitas bila IMT dari 95 persentil ke atas.

\section{Subjek}

Populasi merupakan seluruh objek atau variabel yang terkait masalah penelitian.Populasi dalam penelitian ini adalah seluruh remaja akhir yang ada di Kota Denpasar.Pada penelitian ini, peneliti membagi subjek penelitian kedalam dua kriteria, yaitu kriteria inklusi dan kriteria eksklusi. Subjek penelitian yang digunakan untuk penelitian ini diambil dari populasi yang memenuhi kriteria inklusi meliputi Remaja yang berusia 17 hingga 19 tahun, Subjek telah tinggal di Kota Denpasar dalam kurun waktu sekurang-kurangnya 10 tahun,dan remaja bersedia menjadi subjek.

Metode pengambilan sampel yang digunakan dalam penelitian ini dilakukan dengan melalui dua kali teknik pengambilan sampel yaitu cluster samplingdan purposive sampling.Pada tahap pertama peneliti, membagi daerah asal subjek.Kriteria adalah remaja yang berasal dari kota Denpasar, maka peneliti mengambil subjek yang berasal dari beberapa kecamatan di Denpasar, yaitu Denpasar Utara dan Denpasar Barat dengan teknik cluster sampling. Cluster sampling merupakan teknik pengambilan subjek ataupun sampel dengan cara random dan biasanyadigunakan untuk cakupan area yang luas seperti negara, provinsi, kabupaten dan sebagainya (Sugiyono, 2012). Setelah itu peneliti hanya akan memilih beberapa remaja yang ada di setiap kecamatan dengan pendekatan kepada setiap sekolah-sekolah negeri maupun swasta dengan teknik purposive sampling. Purposive sampling adalah teknik pengambilan sampling dengan pertimbangan tertentu (Sugiyono, 2012).

\section{Tempat penelitian}

Subjek dalam penelitian ini merupakan remaja akhir di Kota Denpasar yang berasal dari beberapa kecamatan di Kota Denpasar, yaitu Denpasar Utara dan Denpasar Barat. Subjek berasal dari beberapa remaja yang ada di setiap kecamatan dengan pendekatan kepada setiap sekolah-sekolah negeri maupun swasta.

Dalam menentukan jumlah populasi pada penelitian ini menggunakan rumus jumlah sampel menurut Yamane (1967) sehingga diperoleh hasil jumlah sampel dalam penelitian ini yaitu 280 siswa.

\section{Alat ukur}

Skala pengukuran regulasi diriyang merupakan landasan teori dari Brown \& Miller (1991). Kuesioner ini menggunakan skala Likert, dimana akan disediakan lima pilihan jawaban. Untuk aitem favorable yaitu Sangat Setuju (SS) dengan nilai 5, Setuju (S) dengan nilai 4, Ragu-Ragu (R) dengan nilai 3, Tidak Setuju (TS) dengan nilai 2, dan Sangat Tidak Setuju (STS) dengan nilai 1.Untuk aitem unfavorable yaitu Sangat Setuju (SS) dengan nilai 1, Setuju (S) dengan nilai 2, Ragu-Ragu (R) dengan nilai 3, Tidak Setuju (TS) dengan nilai 4, dan Sangat Tidak Setuju (STS) dengan nilai 5. Pengukuran pengukuran status gizi. Untuk pengukuran status gizi dilakukan dengan mengukur Indeks Massa Tubuh (IMT) dari subjek penelitian, dengan rumus:

$$
\mathrm{IMT}=\frac{\text { Berat Badan }(\mathrm{kg})}{(\text { Tinggi Badan }(\mathrm{m}))^{2}}
$$

Setelah mendapat hasil IMT dari subjek penelitian, klasifikasikan status gizi subjek penelitian tersebut dengan menggunakan panduan kurva CDC.Status gizi kurang bila IMT dibawah 5 persentil, status gizi normal bila IMT dari 5 persentil sampai dibawah 85 persentil, status gizi lebih bila IMT dari 85 persentil sampai dibawah 95 persentil dan obesitas bila IMT dari 95 persentil ke atas.

\section{Metode pengumpulan data}

Metode pengumpulan data yang digunakan dalam penelitian ini adalah dengan menggunakan 2 alat ukur, yaitu kuesioner regulasi diri dan antropometri gizi. Kuesioner regulasi diri digunakan untuk mengukur regulasi diri pada remaja dan antropometri gizi digunakan untuk mengukur status gizi berdasarkan pendekatan indeks massa tubuh dan untuk pengkategorisasian berdasarkan kurva grafik pertumbuhan yaitu kurva CDC. Pada saat pengumpulan data dilakukan dengan mengajukan surat permohonan ijin penelitian pada tiap sekolah yang menjadi sasaran penelitian. Setelah surat permohonan ijin diterima, peneliti akan bersosialisasi terlebih dahulu pada tiap-tiap wali kelas untuk mempermudah pendekatan kepada calon subjek.

\section{Teknik analisis data}

Validitas berasal dari kata validity yang mempunyai arti sejauh mana ketepatan dan kecermatan suatu alat ukur dalam melakukan fungsi ukurnya atau memberikan hasil ukur yang akurat dan tepat sesuai dengan tujuan pengukuran tersebut (Azwar, 1998). Penelitian ini menggunakan uji validitas konstruk dan validitas isi, pengujian validitas konstruk dilakukan dengan mencari koefisien korelasi aitem total (rix) dengan bantuan perangkat lunak SPSS 17.0). Suatu aitem dapat dikatakan valid apabila skor corrected total aitem correlation lebih besar dari 0,25. Validitas isi menunjukkan sejauh mana suatu aitem-aitem pada alat ukur dapat 


\section{A. A. I. M. PRAMITYA DAN T. D VALENTINA}

mencerminkan keseluruhan konten atau kawasan isi yang hendak diukur secara komprehensif, relevan dan tidak keluar dari batasan tujuan pengukuran. Pengukuran terhadap validitas isi dilakukan dengan teknik professional judgement yang dilakukan oleh dosen pembimbing skripsi dan penyesuaian aitem-aitem dalam alat ukur tersebut dengan cetak biru (blue print) atau indikator perilaku yang hendak diukur (Azwar, 2000). Validitas isi dalam penelitian ini menggunakan professional judgement, yang dilakukan dengan menilai aitemaitem skala pengukuran terkait penggunaan tata bahasa yang kurang efektif, kemudian aitem-aitem yang kurang efektif tersebut diperbaiki, agar skala tersebut dapat dinyatakan valid dalam hal validitas isi. Suatu alat ukur dapat dikatakan memiliki validitas yang tinggi jika hasilnya sesuai dengan kriteria, dalam arti memiliki kesejajaran antara tes dan kriteria (Arikunto, 2006).

Reliabilitas memiliki makna yang erat dengan keakuratan ataupun ketepatan suatu alat ukur untuk melakukan proses pengukuran (Azwar, 1998). Reliabilitas memiliki beberapa nama lain seperti konsistensi, kestabilan dan sebagainya, akan tetapi reliabilitas mempunyai maknan inti yang terkandung yaitu kemampuan suatu alat ukur dapat diandalkan dalam proses pengukuran. Konteks reliabilitas sebagai alat ukur sangat erat kaitannya dengan permasalahan (eror) pengukuran. Hal tersebut merajuk pada suatu inkonsistensi hasil pengukuran apabila dilakukan pada kelompok subjek yang sama. Maka dari itu, walaupun alat ukur sebelumnya telah digunakan dalam sebuah penelitian masih tetap perlu dilakukan komputasi koefisien reliabilitas (Azwar, 2010). Pada penelitian ini, komputasi dibantu dengan perangkat lunak SPSS 17 dengan menggunakan Formula Alpha dari Cronbach.

Sebelum melangkah pada uji analisis data, peneliti terlebih dahulu melakukan uji asumsi yang terdiri dari uji normalitas dan uji linearitas sebagai syarat melakukan uji analisis statistik tertentu. Uji normalitas dilakukan untuk melihat penyimpangan frekuensi observasi distribusi gejala yang diteliti dari frekuensi teoritik kurva normal, atau untuk mengetahui normal atau tidaknya sebaran skor variabel regulasi diri dan status gizi. Uji normalitas sebaran data penelitian akan menggunakan teknik Kolmogorov-Smirnov Goodness of Fit Test. Data dalam penelitian dapat dikatakan berdistribusi normal apabila memiliki nilai $\mathrm{P}>0,05$ (Arikunto, 1988).

Uji linearitas dilakukan untuk mengetahui hubungan yang linear antara kedua variabel penelitian. Adanya hubungan yang linear antara kedua variabel merepresentasikan bahwa perubahan pada variabel prediktor cenderung diikuti oleh perubahan variabel kriterium dengan membentuk garis linear. Apabila hasil analisis uji linearitas memperoleh nilai $(\mathrm{P}<0,05)$ itu menandakan ada hubungan antara kedua variabel (Arikunto, 1988).
Metode analisis data menggunakan peneliti menggunakan analisis statistik nonparametrik Spearman. Metode statistik nonparametrik merupakan metode statistik yang dapat digunakan dengan mengabaikan asumsi-asumsi yang melandasi penggunaan metode statistik parametrik, terutama yang berkaitan dengan distribusi normal. Peneliti mnggunakan uji statistik nonparametrik terkait juga akan hasil dari uji asumsi yang akan dibahas lebih lanjut pada hasil penelitian.

\section{HASIL PENELITIAN}

Uji coba alat ukur dalam penelitian ini dilakukan terhadap subjek penelitian, yaitu siswa SMA Negeri di kota Denpasar yang dilaksanakan pada 29 November-30 November 2012. Uji coba penelitian ini dilakukan dengan menyebarkan kuesioner kepada 200 orang subjek. Data yang telah diperoleh pada saat melakukan uji coba alat ukur penelitian akan dianalisis untuk mengetahui validitas dan reliabilitasnya. Berdasarkan hasil uji coba item yang terdiri dari 63 aitem kepada 200 orang subjek, diperoleh koefisien korelasi yang bergerak dari 0,028 - 0,487. Sesuai dengan taraf signifikan $5 \%$ pada tabel korelasi product moment dengan nilai kritis koefisien korelasi ( $\mathrm{t}$ tabel) sebesar 0,113, menyatakan bahwa suatu aitem dapat dinyatakan valid apabila nilai $r$ hitung $>r$ tabel, dalam penelitian ini aitem yang memiliki nilai koefisien korelasi dibawah nilai kritis koefisien korelasi (t tabel) digugurkan, sehingga terdapat 7 aitem gugur dan 56 aitem valid pada skala regulasi diri dengan indeks koefisien korelasi yang bergerak dari 0,273 sampai dengan 0,625.

Berdasarkan hasil pengujian reliabilitas koefisien alpha $(\alpha)$ pada skala regulasi diri saat uji coba adalah 0,893 , sedangkan hasil koefisien alpha $(\alpha)$ pada saat penelitian adalah 0,936, hal ini menunjukkan bahwa alat ukur regulasi diri dalam penelitian ini memiliki reliabilitas yang baik. Dari hasil uji normalitas awal dengan subjek 280 orang, diketahui bahwa sebaran data pada variabel regulasi diri memiliki nilai signifikansi dengan probabilitas (p) 0.187 atau memiliki probabilitas diatas 0,05 ( $\mathrm{p}>0,05)$, hal tersebut menunjukan bahwa data berdistribusi normal. Untuk sebaran data variabel memiliki nilai signifikansi dengan probabilitas (p) 0,000 atau memiliki probabilitas dibawah 0,05 ( $p<0,05)$, hal tersebut menunjukkan bahwa data berdistribusi tidak normal. Hasil uji linearitas penelitian memiliki nilai signifikansi dengan probabilitas (p) 0,709 atau memiliki probabilitas di atas 0,05 ( $p>0,709$ ), hal tersebut menunjukkan bahwa data penelitian bersifat tidak linier. Salah satu data yaitu pada variabel status gizi mempunyai sebaran tidak normal dan dari uji linearitas bersifat tidak linier. Kedua syarat uji asumsi tidak terpenuhi, untuk itu peneliti menggunakan uji statistik nonparametrik. Uji statistik nonparametrik yang digunakan yaitu Spearman. 
Tabel.1

Hasil uji korelasi nonparametrik

\begin{tabular}{cl|r|r}
\hline & Xregulasidiri & Ystatusgizi \\
\hline Spearman's rho Xregulasi diri & Correlation & 1.000 & .014 \\
& Coefficient & & \\
Sig. (2-tailed) & 280 & .822 \\
$\mathrm{~N}$ & .014 & 1.000 \\
\hline Ystatusgizi Correlation & & \\
Coefficient & .822 & \\
Sig. (2-tailed) & 280 & 280 \\
$\mathrm{~N}$ & & \\
\hline
\end{tabular}

Berdasarkan hasil analisis data, diperoleh nilai signifikansi p sebesar 0,822 atau lebih besar dari 0,05 pada taraf signifikan 0,05, sehingga dapat disimpulkan bahwa tidak ada hubungan antara regulasi diri dengan status gizi pada remaja akhir di Kota Denpasar, sehingga hipotesis alternatif (Ha) yang berbunyi "Ada hubungan antara regulasi diri dengan status gizi remaja akhir di Kota Denpasar" ditolak sedangkan hipotesis nol (Ho) yang berbunyi "Tidak ada hubungan antara regulasi diri dengan status gizi remaja akhir di Kota Denpasar" diterima.

Adapun pengkategorian kelompok yang memiliki skor regulasi diri dan status gizi dari yang paling tinggi hingga yang paling rendah. Pengkategorian ini dilakukan dengan menggunakan rumus pengkategorian skor dari Azwar (2000).

Tabel 2.

Kategori skor regulasi diri

\begin{tabular}{cccrr}
\hline Variabel & Rentang Nilai & Kategori & Subjek & Persentase \\
\hline & $\mathrm{X} \leq 137,1$ & Sangat Rendah & 1 orang & $0,4 \%$ \\
& $137,1 \leq \mathrm{X} \leq 157,7$ & Rendah & 10 orang & $3,6 \%$ \\
Regulasi Diri & $157,7 \leq \mathrm{X} \leq 178,3$ & Sedang & 61 orang & $21,8 \%$ \\
& $178,3 \leq \mathrm{X} \leq 198,9$ & Tinggi & 58 orang & $20,7 \%$ \\
& $198,9<\mathrm{X}$ & Sangat Tinggi & 150 orang & $53,6 \%$ \\
\hline Jumlah & & 280 orang & $100 \%$ \\
\hline
\end{tabular}

Tabel 3.

Kategorisasi status gizi

\begin{tabular}{ccccr}
\hline Variabel & $\begin{array}{c}\text { Rentang Nilai } \\
(\mathrm{BMI})\end{array}$ & Kategori & Subjek & Persentase \\
& $12-18$ & Gizi Kurang & 93 orang & $33,2 \%$ \\
\multirow{3}{*}{ Regulasi Diri } & $19-26$ & Gizi Normal & 171 orang & $61,1 \%$ \\
& $27-29$ & Gizi Lebih & 12 orang & $4,3 \%$ \\
& $\geq 30$ & Obesitas & 4 orang & $1,4 \%$ \\
\hline & Jumlah & & 280 orang & $100 \%$ \\
\hline
\end{tabular}

Berdasarkan tabel di atas, maka dapat ditarik kesimpulan bahwa sebagian besar subjek penelitian berada pada skor regulasi yang sangat tinggi dan berada pada status gizi normal.

\section{PEMBAHASAN}

Ditolaknya hipotesis yang menyatakan bahwa adanya hubungan yang signifikan antara regulasi diri terhadap status gizi dapat disebabkan oleh berbagai hal seperti dikarenakan oleh alasan metodologi. Moleong (2004) menjelaskan bahwa metodologi pada penelitian kuantitatif mempunyai karakteristik salah satunya, metodenya ditentukan terlebih dahulu, tidak luwes, dijabarkan secara rinci terlebih dahulu sebelum dilakukan penelitian. Hal ini tentunya berbeda dengan penelitian sebelumnya yang menjadi latar belakang penelitian hubungan regulasi diri terhadap status gizi yaitu penelitian yang menggunakan metodelogi penelitian kualitatif. Widhiarso (2012) menjelaskan lebih lanjut hasil uji statistik dapat menuai hasil tidak signifikan karena teori yang digunakan untuk membangun hipotesis awal kurang kuat, belum banyak diuji dalam penelitian lain, maupun kurang cocok dengan sampel yang digunakan. Akan tetapi signifikansi dalam statistik yaitu seperti adanya hasil uji statistik yang secara signifikan maupun tidak signifikan merupakan hal yang memang sudah lumrah terjadi pada setiap hasil penelitian.

Pada bab II yaitu tinjauan pustaka, telah dibahas mengenai faktor-faktor yang mempengaruhi status gizi selain pengetahuan gizi yang berhubungan dengan regulasi diri, seperti faktor internal yaitu genetik, asupan makanan, dan penyakit infeksi serta faktor eksternal yaitu pertanian, ekonomi, sosial budaya dan pengetahuan diri. Untuk mendapatkan pemahaman lebih lanjut mengenai hal-hal yang berhubungan dengan status gizi, peneliti kembali mengkaji faktor-faktor tersebut melalui data demografik yang ada pada setiap sampel untuk mendeskripsikan lebih jelas faktor-faktor yang berkontribusi pada status gizi remaja. Peneliti membuat karakteristik subjek penelitian remaja di Denpasar sesuai dengan faktor-faktor yang berhubungan dengan status gizi.

Berdasarkan jenis kelamin, karakteristik subjek penelitian remaja di Kota Denpasar terdapat jumlah laki-laki sebanyak 120 dengan persentase sebanyak $42,9 \%$ dan perempuan sebanyak 160 dengan persentase sebanyak 57,1\% yang telah berpartisipasi dalam penelitian ini.

Peneliti mendapatkan hasil bahwa rata-rata remaja di Denpasar mempunya status gizi yang normal yaitu sebesar 171 remaja dengan persentase $61,1 \%$. Berdasarkan asumsi peneliti, dibuktikan dengan 231 remaja Denpasar dengan persentase $82,5 \%$ mengatakan bahwa remaja tersebut tidak mempunyai keluarga yang memiliki permasalahan gizi, baik obesitas maupun anemia dan sisanya sebanyak 49 remaja Denpasar baik dari remaja laki-laki maupun perempuan dengan persentase $17,5 \%$ yang mengatakan bahwa remaja tersebut mempunyai keluarga yang memiliki permasalahan gizi, baik obesitas maupun anemia. Selain itu terdapat 251 remaja dengan persentase $89,6 \%$ memiliki asupan makanan yang cukup yang peneliti dari perhitungan kebutuhan energi anak-anak dan remaja menurut golongan umur (WHO, 1973). Dilihat dari segi ekonomi terdapat 203 remaja Denpasar yang memiliki pendapatan orang tua kurang dari rata-rata (3,5 juta) dengan persentase $72,5 \%$, untuk segi sosial budaya rsebanyak 260 remaja Denpasar dengan persentase $92,9 \%$ tidak memiliki kepercayaan khusus dalam mengkonsumsi makanan sehinggan dapat mengkonsumsi makanan sperti biasa sehingga mendapatkan asupan makanan yang cukup. Sebanyak 264 remaja di Denpasar dengan persentase 94,3\% tidak memiliki penyakit infeksi seperti cacingan dan diare. Penyakit infeksi 


\section{A. A. I. M. PRAMITYA DAN T. D VALENTINA}

tersebut memberikan pengaruh dalam pembentukan status gizi yang normal dan terakhir didukung oleh letak geografis tempat tinggal remaja dimana Kota Denpasar merupakan lahan sektor pertanian yang kuat sebagaimana yang dipaparkan oleh Wisnu (dalam harian Bali Post, 2009).

Paparan mengenai faktor-faktor yang mempengaruhi status gizi tersebut didukung oleh beberapa penelitian dan pernyataan beberapa ahli. Sebagaian besar subjek penelitian pada penelitian ini memiliki status gizi normal dan dilihat dari karakteristik genetik sebagian besar $(57,1 \%)$ pula dinyatakan bahwa subjek penelitian tidak memiliki keturunan (dilihat dari keluarga) yang mempunyai permasalahan gizi. Hal ini menunjukkan bahwa faktor genetik memiliki keterkaitan dengan status gizi. Pernyataan tersebut didukung oleh jurnal penelitian yang membahas tentang permasalahan gizi oleh Wangsaseputra, Baharsena dan Saanin (2012). Pada jurnal tersebut dijelaskan bahwa faktor genetik memberikan kontribusi terhadap pembentukan status gizi. Hal ini dipertegaskan kembali oleh Meyer dan Stunkard (dalam Taylor, 2009) bahwa orang tua yang memiliki permasalahan gizi kecenderungan mempunyai anak yang juga memiliki permasalahan gizi dan begitupula sebaliknya.

Karakteristik lain seperti faktor penyakit infeksi disebutkan bahwa sebagian besar pula (94,3\%) subjek penelitian tidak memiliki penyakit infeksi khusus sehingga mendukung status gizi subjek penelitian dalam keadaan normal dan sisanya sebanyak $5,7 \%$ subjek penelitian memiliki penyakit infeksi dan diduga mempunyai keterkaitan dengan status gizi di luar normal (gizi kurang). Asumsi peneliti tersebut didukung oleh Siagian (2006) yaitu jurnal penelitian yang membahas gizi, imunitas dan penyakit infeksi oleh yang menjelaskan bahwa adanya keterkaitan antara penyakit infeksi dengan status gizi. Penyakit infeksi berkontribusi dalam pembentukan status gizi karena apabila individu memiliki penyakit infeksi seperti diare akan menyebabkan menurunnya fungsi imunitas tubuh. Lesourd (dalam Siagian, 2006) lebih mempertegas bahwa kekurangan energi protein, misalnya, antara lain menyebabkan penurunan pada proliferasi limposit, produksi sitokin, dan respons antibodi terhadap vaksin.

Dari segi asupan makanan, didapat $89,6 \%$ subjek penelitian memiliki asupan makanan yang cukup (berdasarkan standar kebutuhan energi remaja dari FAO/WHO, 1973). Perhitungan asupan makanan tersebut didapatkan dengan menghitung jumlah kalori perhari masing-masing subjek penelitian berdasarkan makanan (termasuk makanan lengkap 4 sehat 5 sempurna dan jenis makanan lain seperti makanan cepat saji dan camilan) yang subjek penelitian makan setiap harinya yang dilaporkan melalui pengisian data demografik dari kuesioner. Pernyataan tersebut memiliki keterkaitan dengan sebagian besar subjek penelitian memiliki status gizi normal. Kebutuhan energi yang cukup sangat penting bagi remaja. Hal ini dipertegas oleh Kartasapoetra dan Marsetyo (dalam Isdaryanti, 2007) bahwa Energi diperlukan untuk proses metabolisme dalam tubuh individu seperti proses peredaran dan sirkulasi darah, denyut jantung, pernafasan, pencernaan, proses fisiologis lainnya, untuk bergerak atau melakukan pekerjaan fisik. Timbulnya energi dalam tubuh disebabkan oleh pembakaran karbohidrat, protein, dan lemak. Untuk itu perlunya mengkonsumsi makanan yang sehat baik untuk pemenuhan nutrisi dalam tubuh. Sel-sel tubuh yang rusak dapat dibangun dengan mengkonsumsi protein yang cukup. Selain itu, mengkonsumsi makanan yang sehat dengan memerhatikan jenis makanan yang sehat akan dapat menghasilkan energi yang dapat membentuk zat-zat pengatur seperti enzim dan hormon membentuk zat anti energi yang tiap gram protein menghasilkan sekitar 4,1 kalori. Oleh karena individu patut memperoleh energi yang cukup dari mengkonsumsi nutrisi seperti karbohidrat, lemak, dan protein karena hal tersebut sebagai langkah awal pembentukan status gizi (Soematri, 1978).

Karakteristik status gizi normal yang dimiliki oleh remaja di Kota Denpasar diikuti pula dengan karakteristik sektor pertanian yang dimana Kota Denpasar memiliki lahan pertanian yang cukup luas. Hal ini didukung oleh pernyataan dari Suhardjo (2003) yang membahas tentang faktor-faktor yang mempengaruhi status gizi yaitu sektor pertanian yang melibatkan penanaman sampai produksi yang lancar secara tidak langsung dapat mempengaruhi pembentukan status gizi yang baik ataupun normal. Pernyataan tentang sector pertanian ini didukung oleh Wisnu (dalam harian Bali Post, 2009) mengatakan Bali memiliki lahan pertanian 81 hektar dan produksi pangan tetap stabil.

Status gizi normal yang dimiliki remaja di Kota Denpasar pada penelitian ini diikuti pula dengan karakteristik status ekonomi yaitu pendapatan orang tua remaja sebagian besar memiliki pendapatan orang tua kurang dari rata-rata yaitu 3,5 juta (berdasarkan standar yang ditetapkan peneliti dari hasil survei pendapatan orang tua remaja Denpasar saat penelitian). Karakteristik ekonomi tersebut didukung oleh sebuah jurnal penelitian Fakultas Agrikultur Universitas Andalas, Sayuti dan Effendi (2004) menyebutkan bahwa status ekonomi mempengaruhi pola konsumsi pangan yang meliputi pendapatan, besar keluarga, dan tingkat pendidikan. Pendapatan akan menentukan daya beli. Semakin meningkat pendapatan maka semakin beragam susunan makanan yang dikonsumsi dan meningkat pula proporsi pangan hewani yang dikonsumsi. Pangan hewani merupakan pangan yang berkualitas yang mengandung protein yang bermutu tinggi.

Dilihat dari segi sosial dan budaya, terdapat 92,9\% subjek penelitian tidak memiliki pantangan khusus dalan hal makanan. Hal ini diikuti oleh status gizi subjek penelitian remaja di Kota Denpasar memiliki status gizi normal. Kondisi tersebut diperjelas oleh Baliwati, Khomsan dan Dwiriani (dalam Harnany 2006) menyebutkan berbagai masalah gizi 
yang timbul akibat pemenuhan gizi yang kurang mencukupi karena masalah pangan yang terkait dengan ketersediaan pangan dan kerawanan konsumsi pangan yang dipengaruhi oleh kemiskinan, rendahnya pendidikan, dan adat/kepercayaan yang terkait dengan tabu makanan. Jadi, apabila tidak ada pantangan khusus ataupun kepercayaan khusus dalam hal konsumsi pangan dapat mengarahkan ke pembentukan ke status gizi yang baik ataupun normal. Berkaitan dengan sosial dan budaya, penelitian tentang citra tubuh yang berkaitan dengan status gizi oleh Handayani (2009) memaparkan lebih lanjut remaja di Indonesia yang masih menganut nilai agama yang tinggi dan belum terpengaruh budaya asing cenderung mempunyai penerimaan tentang citra tubuh yang masih baik. Hal ini sejalan dengan temuan pada penelitian Furnham dan Alibai (dalam Matsumoto \& Juang, 2008) yang menyatakan rata-rata orang Asia mempunyai bentuk tubuh yang tidak lebih ramping dari orang Eropa. Berdasarkan hal tersebut dapat disimpulkan nilai budaya memiliki implikasi terhadap bentuk tubuh dan hal itu secara tidak langsung berhubungan dengan status gizi.

Penelitian ini memiliki beberapa keterbatasan, yakni diantaranya keterbatasan peneliti dalam membangun konsep teoretis yang disebabkan oleh keakuratan dalam mengoperasionalisasikan konsep teoretis yang menjadi indikator perilaku. Selain itu, dari segi alat ukur, skala regulasi diri yang digunakan kurang dispesifikan langsung dengan status gizi. Untuk metode pengambilan sampel terdapat cara pengambilan sampel yang tidak random pada saat penentuan kelas. Hal tersebut mengakibatkan sampel dalam penelitian ini kurang representatif.

Saran praktis yang ditujukan masyarakat khususnya remaja bahwa Remaja diharapkan memerhatikan asupan makanan yang seimbang agar terbentuknya kondisi status gizi yang normal dan seimbang. Hal tersebut dapat dilakukan dengan makan 4 sehat 5 sempurna, mengurangi makanan cepat saji dan camilan, serta melakukan olahraga. Tidak dianjurkan untuk melakukan diet secara ekstrim sehingga mengarah pada pembentukan gizi yang kurang ataupun perilaku makan yang menyimpang karena hal tersebut dapat merusak kesehatan.

Saran bagi penelitian selanjutnya yaitu mengingat regulasi diri mempunyai kontribusi yang sangat kecil terhadap pembentukan status gizi, sehingga ada baiknya melihat dari faktor-faktor lain yang kemungkinan berpengaruh. Bagi peneliti selanjutnya yang tertarik untuk menindak lanjuti penelitian ini disarankan untuk mengontrol variabel lain contohnya motivasi berprestasi sebagai pembanding ataupun untuk menciptakan penemuan baru dalam menguji suatu teori.

Peneliti lain juga disarankan memperhatikan metode penelitian yang akan digunakan dan memperhatikan penelitian-penelitian sebelumnya yang terkait. Tidak terbuktinya hipotesis dalam penelitian ini salah satunya disebabkan karena masalah metodologi, untuk itu akan lebih baik jika peneliti selanjutnya melakukan penelitian replikasi dengan memperhatikan lebih seksama persoalan-persoalan metodologi.

Uji analisis statistik dalam penelitian ini memakai analisis nonparametrik Spearman, peneliti berikutnya disarankan mampu menggunakan analisis lain, seperti parametrik regresi ganda atau menggunakan uji perbedaan, namun dengan syarat terpenuhnyai uji asumsi. Contohnya membedakan regulasi diri antara remaja laki-laki dan perempuan diikuti oleh variabel lainnya selain status gizi. Penambahan instrumen penelitian dengan wawancara agar memperoleh data yang lebih kaya serta pemahaman yang mendalam dan tidak hanya menggunakan skala juga disarankan oleh peneliti. Hal ini menjadi pertimbangan untuk peneliti selanjutnya agar bisa mengukur variabel penelitian lebih dalam.

\section{DAFTAR PUSTAKA}

Almatsier, S. (2005). Prinsip dasar gizi. Jakarta: Gramedia Pustaka Utama.

Alwisol. (2004). Psikologi kepribadian. Malang: Universitas Muhammadiyah.

Angelina, Z. (6 Juni 2010). Obesitas pada anak. Bali Post. Akses: 23 April

2013 ,

http://www.balipost.co.id/mediadetail.php?module=detailbe rita\&kid=24\&id=36569

Anna, L.K. (21 November 2011). Obesitas ancam remaja. Kompas. Akses: $23 \quad$ April 2013, http://health.kompas.com/read/2011/11/21/07373137/Obesi tas.Ancam.Remaja

Arikunto, S. (1988). Statistik jilid I. Yogyakarta: Fakultas Psikologi Universitas Gadjah Mada.

Azwar, S. (2010). Reliabilitas dan validitas. Yogyakarta: Pustaka Pelajar.

Azwar, S. (2000). Penyusunan skala psikologi. Yogyakarta: Pustaka Pelajar.

Azwar, S. (2000). Signifikan atau sangat Signifikan?. Akses: 14 Januari 2013 , http://azwar.staff.ugm.ac.id/files/2012/04/TIDAK_SIGNIFI KAN_SIGNIFIKAN.pdf

Baliwati,F.Y., Khomsan, A. \& Dwiriani, C.M. (2010). Pengantar pangan dan gizi. Jakarta: Swadaya

Bandura, A. (1986). Social foundation of thought and action: a social cognitive theory. New Jersey: Prentice Hall

Baumeister, R.F \& Vohs, K.D. (2007). Self-regulation, egodepletion and motivation. Social and Personality Psychology, 2-3.

Damayanti, M. (2009). Overview adolescent health problem and services. Indonesian Pediatric Society. Akses: 1 Oktober 2012, www.idai.or.id.

Damanik, H.M. (2010). Pola makan dan status gizi anak sekolah dasar fi desa perbukitan dan di desa tepi danau kecamatan panguruan kabupaten samosir. Akses: 24 April 2013, http://repository.usu.ac.id/bitstream/123456789/22464/7/co ver.pdf. 


\section{A. A. I. M. PRAMITYA DAN T. D VALENTINA}

Disperindagbali. (2010). Kelembagaan disperindag provinsi bali. Bali Mandara, www.disperindagbaliprov.go.id. Akses: 28 Februari 2013.

Harnany. (2006). Pengaruh tabu makanan, tingkat kecukupan gizi, konsumsi tablet besi dan teh terhadap kadar hemoglobin ada ibu hamil di kota pekalongan. Magister Gizi Masyarakat Universitas Diponegoro. Akses: 28 Februari 2013,

http://eprints.undip.ac.id/15216/1/Afiyah_Sri_Harnany.pdf.

Handayani, M. (2009). Faktor-faktor yang mempengaruhi distorsi citra tubuh siswa SMAN 1 pamulang. Program Studi Kesehatan Masyarakat Universitas Islam Nasional Syarif Hidayatullah. Akses: 24 April 2013 http://perpus.fkik.uinjkt.ac.id/file_digital/skripsi\%20miratn a\%20handayani.pdf.

Harlyan, L.I. (2012). Uji hipotesis. Departemen Sumber Daya Perikanan Universitas Brawijaya. Akses: 23 April 2013, http://ledhyane.lecture.ub.ac.id/files/2012/11/PENGUJIANHIPOTESIS.pdf

Hasan, I. (2005). Pokok-pokok materi statistik 2 (statistik inferensif). Jakarta : Bumi Aksara.

House of Common, (2004). Obesity. Akses 28 Februari 2013, www.publicationparliament.com.

Ipa, A. \& Sirajuddin. (2010). Status gizi anak sekolah keluarga nelayan di SDN 40 Lumpangang desa biangkeke kabupaten bantaeng. Media Gizi Pangan. Vol. 9. Akses: 24 April 2013,

https://jurnalmediagizipangan.files.wordpress.com/2012/03 /10-status-gizi-anak-sekolah-keluarga-nelayan-di-sdn-40lumpangang-desa-biangkeke-kabupaten-bantaeng.pdf.

Isdaryanti, C. (2007). Asupan energi protein, status gizi dan prestasi belajar anak sekolah dasar arjowinangun I pacitan. Yogyakarta: Universitas Gadjah Mada.

Khomsan, A. (2003). Pangan dan gizi untuk kesehatan. Jakarta: PT.Rajagrafindo Persada.

Lailani, M. (2010). Makanan siap saji memicu obesitas. Akses: 1 Oktober 2010, http://mutialailani.wordpress.com.

Matsumoto, D. \& Juang, L. (2008). Culture and psychology fourth edition. Thomson Wadsworth: USA.

Medicastore. (2010). Obesitas pada remaja. Akses: 28 Februari 2013, http://m.medicastore.com.

Moleong, L.J. (2004). Metodelogi penelitian kualitatif. Bandung: Remaja Rosdakarya.

Mulyani, E. (2009). Konsumsi kalsium pada remaja di SMP 201 jakarta barat. Akses: 4 Februari 2013, http://lontar.ui.ac.id/file?file=digital/126116-S-5733Konsumsi\%20kalsium-Pendahuluan.pdf.

Ningrum, R.P., \& Hasanat., N.U. (2001). Dinamika regulasi diri pada penderita diabetes mellitus tipe II, 1ST national conference on biopsychosocial psychology, Akses: 1 Oktober 2012, http://lib.ugm.ac.id/digitasi/upload/2735_MU.11110022.pd $\mathrm{f}$

Notoadmodjo, S. (2003). Pendidikan dan perilaku kesehatan. Jakarta: Rineka Cipta.

Nursalam. (2008). Konsep dan Penerapan Metodologi Penelitian Ilmu Keperawatan. Jakarta: Salemba Medika

Papalia, E.D, Olds,W.S, Feldman, D.R. (2001). Human development edisi kedelapan. New York: Mc-Graw-Hill, Inc
Purnamasari (2011). Anemia. Akses: 21 September 2012, dyah_purnamasari.blog.unsoed.ac.id.

Risatianti ,K.dkk (2010). "Makanan yang benar sehatkan badan": Program Pendidikan Gizi seimbang untuk anak usia sekolah dengan pendekatan regulasi diri. Gizi Indon 2010, 33(2):126-135 Akses: 1 Oktober 2012, http://www.persagi.org/document/makalah/179_makalah.p df.

Riskesdas (2007). Status Gizi Nasional. Gizi.depkes.co.id. Akses: 28 Februari 2013.

Riskesdas (2010). Riset kesehatan dasar. Akses: 28 Februari 2013, http://www.litbang.depkes.go.id

Sarafino, E.P. (1998). Health psychology; biopsychosocial interacrions. Third Edition. United States of American: John Wileyz Sonc, Inc.

Satria (2008). Faktor-faktor yang mempengaruhi body image. Akses: 25 Desember 2012, http://id.shyoong.com/medicine-andhealth/diet and exercise/2183446-faktor-faktor yangmempengaruhi-body/.

Sayuti \& Effendi. (2010). Pola konsumsi pangan sumber protein mahasiswa fakultas pertanian universitas andalas. Stigma no. XII No.2 April - Juni 2004. Akses: 28 Frebruari 2013, https://www.google.co.id/url?.unand.ac.id_SayutiEffendi.doc.

Setiawan, R. (2004). Pengantar statistika. Yogyakarta: Pustaka Pelajar.

Setiadi (2008). Keperawatan Keluarga. Jakarta: EGC.

Siagian (2006). gizi, imunitas, dan penyakit infeksi. Departemen Gizi dan Kesehatan Masyarakat FKM USU. Akses: 28 Februari 2013,

http://repository.usu.ac.id/bitstream/123456789/18924/1/ik m-des2006-10\%20(2).pdf

Siagian (2011). Citra tubuh dan gangguan makan pada remaja. Akses: 28 Februari 2013, http://www.analisadaily.com.

Soemantri,A.G, 1978, Hubungan anemia kekurangan zat besi dengan konsentrasi dan prestasi belajar. Jakarta: CV. Petra Jaya.

Suci (2008). Perbedaan Self Regulation pada Mahasiswa Bekerja dan tidak bekerja. Jurnal Ilmiah Psikologi Universitas Paramadina, 34-48. Akses: 1 Oktober 2012,http://fpsi.mercubuana-yogya.ac.id/wpcontent/uploads/2012/06/jurnal-fastirola.ok_.pdf.

Sugiyono (2012). Statistika untuk penelitian. Bandung: Alfabeta.

Suhardjo \& Kusharto. (1992). Prinsip-prinsip ilmu gizi. Yogyakarta: Kanisius.

Sulaeman (2009). Hubungan antara tingkat pengetahuan dengan angka kejadian anemia remaja puteri SMUN 1 yogyakarta tahun 2007. Akses: 24 April 2013, http://one.indoskripsi.com/node/8347

Supariasa. (2002). Penilaian status gizi. Jakarta: EGC.

Taylor, S.E. (2009). Health psychology seventh edition. New York: McGraw-Hill Companies.

Tim Penulis Poltekkes Depkes Jakarta I. (2010). Kesehatan remaja; problem dan solusinya. Jakarta: Salemba Medika.

Widhiarso, W. (2012). Hasil uji tidak signifikan, bisa jadi karena penulisan butir kurang tepat. Akses: 14 Januari 2013, http://widhiarso.staff.ugm.ac.id/files/Hasil\%20Uji\%20Tida k\%20Signifikan,\%20Bisa\%20jadi\%20Karena\%20Penulisa n\%20Butir\%20yang\%20Kurang\%20Tepat.pdf. 
Wisnu. ( 21 November 2009). Lahan pertanian harus diselamatkan. Harian Bali Post. Akses: 14 Januari 2013.

Wulandari \& Zulkaida. (2007). Self-regulated behavior pada remaja Puteri yang mengalami obesitas. Repository Universitas Gunadharma. Vol: 2. Akses: 1 Oktober 2012, http://hdl.handle.net/123456789/481.

Zimmerman, B.J. 7 Bandura, A. (1994). Impact of self-regulatory influrnces on writing course Attaimntment. American Education Research Journal. 845-862. Akses: 1 Oktober 2012,

http://www.uky.edu/ eushe2/BanduraPubs/Bandura1994A ERJ.pdf 